\title{
Overweight and Obesity, Body Fat, Waist Circumference, and Anemia in Peruvian University Students: A Cross-Sectional Study
}

\author{
Ruth B. Quiliche Castañeda, ${ }^{1}$ Josué Turpo-Chaparro $\left(\mathbb{D},{ }^{2}\right.$ Jesús Hanco Torres ${ }^{(D)}{ }^{2}$ \\ Jacksaint Saintila $\mathbb{D}^{2,3}$ and Percy G. Ruiz Mamani $\mathbb{B}^{4}$ \\ ${ }^{1}$ Oficina de Nutrición, Vicerrectorado de Bienestar Universitario, Universidad Peruana Unión, Lima, Peru \\ ${ }^{2}$ Escuela de Posgrado, Universidad Peruana Unión, Lima, Peru \\ ${ }^{3}$ Escuela de Nutrición Humana, Facultad de Ciencias de la Salud, Universidad Peruana Unión, Lima, Peru \\ ${ }^{4}$ Escuela Profesional de Enfermería, Facultad de Ciencias de la Salud, Universidad Privada San Juan Bautista, Chorrillos, Peru \\ Correspondence should be addressed to Jacksaint Saintila; jacksaintsaintila@upeu.edu.pe
}

Received 13 July 2021; Revised 18 October 2021; Accepted 29 November 2021; Published 8 December 2021

Academic Editor: Abdah Md Akim

Copyright (c) 2021 Ruth B. Quiliche Castañeda et al. This is an open access article distributed under the Creative Commons Attribution License, which permits unrestricted use, distribution, and reproduction in any medium, provided the original work is properly cited.

\begin{abstract}
The university represents a critical space for students in terms of prevalence of malnutrition. The objective of this study was to determine the body mass index (BMI), body fat percentage (\% BF), waist circumference (WC), and anemia in university students. A cross-sectional study was carried out in 2,285 university students from Lima, Peru. The sample was selected by nonprobability convenience sampling. Anthropometric data and hemoglobin levels were measured. The Chi-square test was used. The analysis of the associated factors was done using binary logistic regression. A significance level of $5 \%$ was considered. There were no significant differences between men and women in BMI $(p>0.05)$. The men presented significantly high and very high levels of $\%$ $\mathrm{BF}(p<0.001)$. The proportion of women who presented anemia and high and very high WC was significantly higher compared to men $(p<0.001)$. Being older than 27 years $\left(\mathrm{OR}_{\mathrm{B}}=2.07 ; 95 \% \mathrm{CI}=1.19-3.6\right)$, being male $\left(\mathrm{OR}_{\mathrm{B}}=2.68 ; 95 \% \mathrm{CI}=2.02-3.55\right)$, studying at the engineering faculty $\left(\mathrm{OR}_{\mathrm{B}}=1.39 ; 95 \% \mathrm{CI}=1.09-1.79\right)$, having excess body fat $\left(\mathrm{OR}_{\mathrm{B}}=8.17 ; 95 \% \mathrm{CI}=6.13-10.87\right)$, and having an elevated $\mathrm{WC}\left(\mathrm{OR}_{\mathrm{B}}=35.51 ; 95 \% \mathrm{CI}=25.06-50.33\right)$ significantly predicted overweight/obesity. The findings of this study suggest that college students, especially males and those who are not enrolled in health sciences colleges, should be a priority in healthy lifestyle interventions, particularly nutritional education programs, to reduce the prevalence of overweight and obesity.
\end{abstract}

\section{Introduction}

The university environment represents a critical space for students regarding the adoption of inappropriate eating habits and a greater risk of overweight and obesity and anemia, characterized particularly by an intake of foods rich in saturated fat and deficient in essential minerals such as iron and folic acid [1].

The prevalence of overweight and obesity has doubled since 1980 and affects almost a third of the world's population, becoming a public health problem and increasing considerably, especially among university students in developing countries [2]. In Peru, obesity is a growing problem. According to the National Institute of Health,
$42.4 \%$ of young people represented by the university population have obesity [3]. Overweight and obesity represent one of the important risk factors for the development of cardiovascular diseases, insulin resistance, glucose intolerance, high blood pressure, and different types of cancer $[4,5]$. These diseases contribute to reducing life expectancy by up to ten years and represent a high economic burden for society [6]. The causes of overweight and obesity are multifactorial; among them, the most prominent are inadequate dietary practices with low consumption of fruits, vegetables, whole grains, and nuts and high consumption of foods with high caloric density [7, 8]. Likewise, sedentary lifestyle and genetic and metabolic factors contribute to the appearance of the disease $[9,10]$. 
On the other hand, another factor that is present is anemia, which is a disorder that is characterized by a hemoglobin concentration below the specific threshold, which creates an impediment to meet the oxygen demands of the tissues [11]. It is estimated that this disease affects 528.7 million women and 273.2 million children under 5 years of age in the world in 2011 [12]. In Peru, according to the National Institute of Statistics and Informatics, $20.7 \%$ of women between 15 and 49 years old had some type of anemia. $17.7 \%$ had mild anemia, $2.8 \%$ moderate anemia, and $0.2 \%$ severe anemia [13].

It is important to study young university students, because this is an important and vulnerable period for adverse behavior change related to weight and risk of anemia [14]. In Peru, some studies have been carried out regarding the prevalence of overweight and obesity [15-17]; however, few have focused on the percentage of body fat, anemia, and cardiovascular risk factors in college students. Consequently, there is an urgent need to analyze the situation in this population group. In this sense, the objective of this study was to determine the $\mathrm{BMI}, \% \mathrm{BF}, \mathrm{WC}$, and anemia in university students.

\section{Materials and Methods}

2.1. Design, Type of Research, and Participants. A crosssectional study was carried out. To obtain the data, students from the first to the tenth cycle of a private university located in the eastern region of Lima, Peru, were evaluated at the beginning of the academic year. The evaluation was carried out during March 2019 (the beginning of academic cycle I). Participants were selected through intentional nonprobability sampling. Those who did not sign the informed consent and who have undergone medical treatment were not eligible to be part of the study. Before collecting the data, the participants were informed about the content of the research (nature, topic, objectives, benefits, among others). In accordance with the ethical standards for data collection (confidentiality and freedom of participation), they have also been assured that their participation was voluntary and anonymous and that they could stop filling out questionnaires and forms at any time, if they so wished. The study was approved by the Research Ethics Committee of the Universidad Peruana Unión and registered under reference number: N ${ }^{\circ} 0011-2019 / \mathrm{UPeU} / \mathrm{FCS} / \mathrm{CIISA}$.

2.2. Anthropometric Measurements: BMI and \% BF. The determinations of anthropometric and hemoglobin $(\mathrm{Hb})$ measurements were carried out in the Nutritional Clinic and the Medical Center of the Universidad Peruana Unión, respectively. Weight and height were measured using a calibrated SECA 700 brand mechanical column, with scale capacity of $220 \mathrm{~kg}$, and measuring range of 60 to $200 \mathrm{~cm}$ (SECA ${ }^{\circledR}$, Hamburg, Germany). The BMI was calculated according to the parameters established by the Ministerio de Salud del Perú and classified as follows: underweight, $<18.5 \mathrm{~kg} / \mathrm{m}^{2}$; normal weight, $\geq 18.5$ to $\leq 24.9 \mathrm{~kg} / \mathrm{m}^{2}$; overweight, between 25.0 and $29.9 \mathrm{~kg} / \mathrm{m}^{2}$; obesity $\geq 30$ [18]. The
WC was determined by means of a self-retracting metallic steel tape measured from Cescorf (Cescorf Equipamentos Para Esporte Ltda-Epp, Brazil). Abdominal obesity was considered for a WC $\geq 94 \mathrm{~cm}$ in men and $\geq 80 \mathrm{~cm}$ in women [18].

The $\%$ BF was determined using a bioelectric impedance (InBody 120, Biospace Co. Ltd., Seoul, Korea), following the recommendations proposed by the Spanish kinanthropometry group of the Spanish federation of sports medicine [19]. The measurement of the total and segmental body composition of the body (arms, legs, and trunk) using the InBody 520 system was made at 5.50 and $500 \mathrm{kHz}$. Adiposity categories were established as low-fat, normal, high-fat, and very high-fat. All procedures were performed according to the manufacturer's instructions, which are based on the work of Gallagher et al. [20].

2.3. $\mathrm{Hb}$ Concentration. Regarding the evaluation of the $\mathrm{Hb}$ concentration, the determination was made using the HemoCue $^{\circledR}$ (HemoCue AB, Hb 201+, Angelhemo, Sweden). Once the hemoglobin value was obtained, it was compared with the cut-off points for age that are established in the Technical Health Standard for the therapeutic and preventive management of anemia in children, adolescents, and pregnant and postpartum women of the Ministry of Health of Peru. $\mathrm{Hb}$ levels were considered normal for men and nonpregnant women aged 15 years and over, with concentrations $\geq 13.0 \mathrm{~g} / \mathrm{dL}$ and $\geq 12.0 \mathrm{~g} / \mathrm{dL}$, respectively [21].

2.4. Statistical Analysis. A descriptive analysis of the anthropometric and $\mathrm{Hb}$ parameters was carried out. Statistical hypothesis tests were carried out to compare the proportions between men and women, and between faculties. Also, the association analysis between sociodemographic characteristics and overweight/obesity was carried out. The Chisquare test was used. The association analysis between the factors associated with overweight/obesity (dependent variable) in students was evaluated using a binary logistic regression model. Age, sex, academic area, excess body fat, and elevated WC were considered as independent variables. These variables had a probability value ( $p$ value) lower than 0.05 in the bivariate analysis; therefore, they were included in the bivariate logistic regression analysis. These analyses were carried out considering a significance level of 5\%. All analyses were done using IBM SPSS statistical software, version 24 (SPSS Inc., Chicago, IL, USA).

\section{Results}

The characteristics of the university students who participated in the study are described in Table 1. It was observed that $15.9 \%$ were under 18 years of age, the majority $(61.4 \%)$ had ages ranging between 18 and 22 years, and few $(4.7 \%)$ were over 27 years. $47.5 \%$ of the students came from the coast of Peru, $29.3 \%$ belonged to the mountains, $15.7 \%$ were from the jungle, and only $7.5 \%$ were foreign students residing in Peru. Regarding marital status, there was a higher representation of single students (98.4\%), while a small 
TABLE 1: Sociodemographic characteristics of university students.

\begin{tabular}{|c|c|c|c|c|c|c|}
\hline \multirow{2}{*}{ Variable } & \multicolumn{2}{|c|}{ Total } & \multicolumn{2}{|c|}{ Women } & \multicolumn{2}{|c|}{ Men } \\
\hline & $n$ & $\%$ & $n$ & $\%$ & $n$ & $\%$ \\
\hline \multicolumn{7}{|l|}{ Age (years) } \\
\hline$<18$ & 363 & 15.9 & 210 & 16.0 & 153 & 15.7 \\
\hline $18-22$ & 1464 & 64.1 & 890 & 67.8 & 574 & 59.0 \\
\hline $23-27$ & 351 & 15.4 & 165 & 12.6 & 186 & 19.1 \\
\hline$>27$ & 107 & 4.7 & 47 & 3.6 & 60 & 6.2 \\
\hline \multicolumn{7}{|l|}{ Origin } \\
\hline Coast & 1086 & 47.5 & 638 & 48.6 & 448 & 46.0 \\
\hline Mountain range & 670 & 29.3 & 368 & 28.0 & 302 & 31.0 \\
\hline Jungle & 358 & 15.7 & 209 & 15.9 & 149 & 15.3 \\
\hline Foreign & 171 & 7.5 & 97 & 7.4 & 74 & 7.6 \\
\hline \multicolumn{7}{|l|}{ Marital status } \\
\hline Single & 2249 & 98.4 & 1300 & 99.1 & 949 & 97.5 \\
\hline Married & 36 & 1.6 & 12 & 0.9 & 24 & 2.5 \\
\hline \multicolumn{7}{|l|}{ Academic area } \\
\hline Humanities & 381 & 16.7 & 137 & 10.4 & 244 & 25.1 \\
\hline Business & 359 & 15.7 & 216 & 16.5 & 143 & 14.7 \\
\hline Health & 880 & 38.5 & 651 & 49.6 & 229 & 23.5 \\
\hline Engineering & 665 & 29.1 & 308 & 23.5 & 357 & 36.7 \\
\hline \multicolumn{7}{|l|}{ Career } \\
\hline Administration & 198 & 8.7 & 122 & 9.3 & 76 & 7.8 \\
\hline Accounting & 162 & 7.1 & 94 & 7.2 & 68 & 7.0 \\
\hline Education & 101 & 4.4 & 74 & 5.6 & 27 & 2.8 \\
\hline Theology & 164 & 7.2 & 0 & 0.0 & 164 & 16.9 \\
\hline Communication & 116 & 5.1 & 63 & 4.8 & 53 & 5.4 \\
\hline Architecture & 122 & 5.3 & 67 & 5.1 & 55 & 5.7 \\
\hline Food engineering & 83 & 3.6 & 59 & 4.5 & 24 & 2.5 \\
\hline Environmental engineering & 187 & 8.2 & 110 & 8.4 & 77 & 7.9 \\
\hline Civil engineering & 172 & 7.5 & 53 & 4.0 & 119 & 12.2 \\
\hline Systems engineer & 100 & 4.4 & 19 & 1.4 & 81 & 8.3 \\
\hline Human medicine & 278 & 12.2 & 167 & 12.7 & 111 & 11.4 \\
\hline Psychology & 297 & 13.0 & 234 & 17.8 & 63 & 6.5 \\
\hline Human nutrition & 174 & 7.6 & 139 & 10.6 & 35 & 3.6 \\
\hline Nursing & 131 & 5.7 & 111 & 8.5 & 20 & 2.1 \\
\hline
\end{tabular}

Note. $n=2285$.

proportion reported being married (1.6\%). In relation to the distribution by academic areas, it was found that $38.5 \%$ of the students were enrolled in health sciences, $29.1 \%$ studied careers related to engineering, $16.7 \%$ studied humanities, and $15.7 \%$ studied business sciences. Fourteen professional careers were reported, where the proportions ranged from $3.6 \%$ to $13 \%$.

Table 2 shows the descriptions about the anthropometric parameters and hemoglobin in men and women.

In Table 3, with respect to BMI, the analyses showed that there were no significant differences between the two groups, because similar proportions were observed in the different categories for BMI. Regarding \%BF, higher proportions of male students with high and very high levels were observed compared to females, and these differences were significant $(p<0.001)$. Regarding WC, higher proportions of female students with high and very high levels were observed compared to males, and these differences were also significant $(p<0.001)$. In addition, significant differences $(p<0.001)$ were found in anemia between men and women, with a higher proportion of women presenting anemia compared to men.
No significant differences $(p>0.05)$ were observed because the proportions of students in the different levels of nutritional status were similar (see Table 4). Similarly, no significant differences $(p>0.05)$ were found between the proportions of students at different body fat levels. Regarding WC, there were higher proportions of students from the academic areas of health and business with high and very high levels compared to students from other academic areas, and these differences were significant $(p<0.001)$. However, obesity and high and very high fat percentage were less frequent in health science students. Likewise, there were significant differences $(p<0.001)$ in the proportions of students presenting anemia among the 4 academic areas, being more prevalent in students in the academic area of health.

With the contrast of proportions, it was found that age (>27 years) was significantly related to overweight/obesity $(p<0.01)$. No significant relationships were found between sex, marital status, and region of origin with overweight/ obesity $(p>0.05)$. In turn, academic area (engineering), body fat, and waist circumference were significantly related to overweight/obesity $(p<0.05)$ (see Table 5$)$.

In the binary logistic regression analysis, factors that were significantly related in the bivariate analysis were considered as predictors of overweight/obesity: age $(0=<27$ years; $1=\geq 27$ years), sex $(0=$ woman, $1=$ man $)$, academic area $(0=$ other, $1=$ engineering $)$, excess body fat $(0=$ no, $1=y e s)$, and elevated abdominal circumference $(0=$ no, $1=$ yes). The results of the multivariate analysis (Table 6) showed that being over 27 years of age $\left(\mathrm{OR}_{\mathrm{B}}=2.07 ; 95 \%\right.$ $\mathrm{CI}=1.19-3.6)$, being male $\left(\mathrm{OR}_{\mathrm{B}}=2.68 ; 95 \% \mathrm{CI}=2.02-3.55\right)$, studying at the academic area of engineering $(\mathrm{ORB}=1.39$; $95 \% \mathrm{CI}=1.09-1.79)$, present excess body fat $\left(\mathrm{OR}_{\mathrm{B}}=8.17\right.$; 95\% $\mathrm{CI}=6.13-10.87)$, and having a high abdominal circumference $(\mathrm{ORB}=35.51 ; 95 \% \quad \mathrm{CI}=25.06-50.33)$ were variables that significantly predicted overweight/obesity.

\section{Discussion}

This study aimed to determine overweight, obesity, \% FB, WC, and anemia in university students. The results showed that the prevalence of overweight and obesity according to BMI among Peruvian university students was similar in both sexes, although the proportion of men who were overweight and obese was slightly higher. On the other hand, binary logistic regression analyses showed that being a man represented a risk factor for excess body weight. One study found that obesity was significantly associated with males [22]. Another study reported that the risk of being overweight and obese was 3.8 times higher among male students [23]. Moreover, recent evidence from studies carried out in Peru shows that Peruvian men have a higher prevalence of overweight and obesity [24]. However, there are discrepancies with the findings reported by Soares and Barreto [25], who reported that Brazilian women are more overweight and obese than men, showing that they have 2.2 times the risk of being overweight or obese compared to men. These results are supported by other findings reported in similar studies, in which it has been observed that gender is a 
TABLe 2: Anthropometric parameters and hemoglobin in university students.

\begin{tabular}{|c|c|c|c|c|c|c|}
\hline \multirow{2}{*}{ Variable } & \multicolumn{3}{|c|}{ Women } & \multicolumn{3}{|c|}{ Men } \\
\hline & M & SD & 95\%CI (LL-UL) & M & SD & 95\%CI (LL-UL) \\
\hline Age (years) & 20.29 & 3.43 & $(20.100-20.471)$ & 21.03 & 3.98 & $(20.782-21.282)$ \\
\hline Weight (kg) & 57.73 & 9.73 & $(57.199-58.253)$ & 66.87 & 11.53 & $(66.149-67.600)$ \\
\hline Height $(\mathrm{cm})$ & 1.55 & 0.06 & $(1.547-1.553)$ & 1.67 & 0.06 & $(1.663-1.671)$ \\
\hline BMI $\left(\mathrm{kg} / \mathrm{m}^{2}\right)$ & 24.01 & 3.64 & $(23.808-24.202)$ & 24.02 & 3.65 & $(23.789-24.248)$ \\
\hline$\% \mathrm{BF}$ & 32.83 & 4.31 & $(32.598-33.064)$ & 22.00 & 6.27 & (21.609-22.398) \\
\hline $\mathrm{WC}(\mathrm{cm})$ & 77.32 & 7.92 & $(76.896-77.754)$ & 81.76 & 8.87 & (81.201-82.318) \\
\hline $\mathrm{Hb}(\mathrm{g} / \mathrm{dl})$ & 13.17 & 1.03 & (13.116-13.228) & 15.24 & 0.95 & $(15.182-15.302)$ \\
\hline
\end{tabular}

Note. $n=2285$; BMI: body mass index; \% BF: body fat percentage; WC: waist circumference; Hb: hemoglobin; CI: Confidence Interval; LL: Lower Limit; UL: Upper Limit; M: mean; SD: standard deviation.

TABLe 3: BMI, \% BF, WC, and anemia in female and male university students.

\begin{tabular}{|c|c|c|c|c|c|c|c|c|}
\hline \multirow{2}{*}{ Variable } & \multicolumn{2}{|c|}{ Total } & \multicolumn{2}{|c|}{ Women } & \multicolumn{2}{|c|}{ Men } & \multirow{2}{*}{$x^{2}$} & \multirow{2}{*}{$p^{*}$} \\
\hline & $n$ & $\%$ & $n$ & $\%$ & $n$ & $\%$ & & \\
\hline \multicolumn{9}{|l|}{ BMI $\left(\mathrm{kg} / \mathrm{m}^{2}\right)$} \\
\hline Under weight & 61 & 2.7 & 33 & 2.5 & 28 & 2.9 & 1.913 & 0.591 \\
\hline Normal & 1487 & 65.1 & 863 & 65.8 & 624 & 64.1 & & \\
\hline Overweight & 596 & 26.1 & 342 & 26.1 & 254 & 26.1 & & \\
\hline Obesity & 141 & 6.2 & 74 & 5.6 & 67 & 6.9 & & \\
\hline \multicolumn{9}{|l|}{$\% \mathrm{BF}$} \\
\hline Low & 12 & 0.5 & 8 & 0.6 & 4 & 0.4 & 243.690 & $<0.001^{* *}$ \\
\hline Normal & 1026 & 44.9 & 649 & 49.5 & 377 & 38.7 & & \\
\hline High & 845 & 37.0 & 564 & 43.0 & 281 & 28.9 & & \\
\hline Very high & 402 & 17.6 & 91 & 6.9 & 311 & 32.0 & & \\
\hline \multicolumn{9}{|l|}{$\mathrm{WC}$} \\
\hline Normal & 1791 & 78.4 & 905 & 69.0 & 886 & 91.1 & 160.765 & $<0.001^{* *}$ \\
\hline High & 357 & 15.6 & 295 & 22.5 & 62 & 6.4 & & \\
\hline Very high & 137 & 6.0 & 112 & 8.5 & 25 & 2.6 & & \\
\hline \multicolumn{9}{|l|}{ Anemia } \\
\hline Yes & 180 & 7.9 & 163 & 12.4 & 17 & 1.7 & 87.756 & $<0.001^{* *}$ \\
\hline No & 2105 & 92.1 & 1149 & 87.6 & 956 & 98.3 & & \\
\hline
\end{tabular}

Note. $n=2285$; BMI: body mass index; \% FB: body fat percentage; WC: waist circumference. ${ }^{*} p$-value. A Chi-square test $(\chi 2)$ was used to evaluate the degree of significance of the anthropometric data and the sex of the participants. $p$ represents the probability that gender is differentiated with anthropometric data and anemia. ${ }^{* *}$ statistical significance.

TABLe 4: BMI, \% FB, WC, and anemia in humanities, business, health, and engineering students.

\begin{tabular}{|c|c|c|c|c|c|c|c|c|c|c|}
\hline \multirow{2}{*}{ Variable } & \multicolumn{2}{|c|}{ Humanities } & \multicolumn{2}{|c|}{ Business } & \multicolumn{2}{|c|}{ Health } & \multicolumn{2}{|c|}{ Engineering } & \multirow{2}{*}{$\chi^{2}$} & \multirow{2}{*}{$p^{*}$} \\
\hline & $n$ & $\%$ & $n$ & $\%$ & $n$ & $\%$ & $n$ & $\%$ & & \\
\hline \multicolumn{11}{|l|}{ BMI $\left(\mathrm{kg} / \mathrm{m}^{2}\right)$} \\
\hline Under weight & 10 & 2.6 & 14 & 3.9 & 24 & 2.7 & 13 & 2.0 & 15.336 & 0.082 \\
\hline Normal & 259 & 68.0 & 222 & 61.8 & 594 & 67.5 & 412 & 62.0 & & \\
\hline Overweight & 94 & 24.7 & 102 & 28.4 & 203 & 23.1 & 197 & 29.6 & & \\
\hline Obesity & 18 & 4.7 & 21 & 5.8 & 59 & 6.7 & 43 & 6.5 & & \\
\hline \multicolumn{11}{|l|}{$\% \mathrm{BF}$} \\
\hline Low & 2 & 0.5 & 1 & 0.3 & 3 & 0.3 & 6 & 0.9 & 16.735 & 0.053 \\
\hline Normal & 165 & 43.3 & 162 & 45.1 & 412 & 46.8 & 287 & 43.2 & & \\
\hline High & 135 & 35.4 & 141 & 39.3 & 335 & 38.1 & 234 & 35.2 & & \\
\hline Very high & 79 & 20.7 & 55 & 15.3 & 130 & 14.8 & 138 & 20.8 & & \\
\hline \multicolumn{11}{|l|}{$\mathrm{WC}$} \\
\hline Normal & 316 & 82.9 & 279 & 77.7 & 670 & 76.1 & 526 & 79.1 & 15.440 & $0.017^{* *}$ \\
\hline High & 56 & 14.7 & 61 & 17.0 & 144 & 16.4 & 96 & 14.4 & & \\
\hline Very high & 9 & 2.4 & 19 & 5.3 & 66 & 7.5 & 43 & 6.5 & & \\
\hline \multicolumn{11}{|l|}{ Anemia } \\
\hline Yes & 21 & 5.5 & 28 & 7.8 & 94 & 10.7 & 37 & 5.6 & 17.383 & $0.001^{* *}$ \\
\hline No & 360 & 94.5 & 331 & 92.2 & 786 & 89.3 & 628 & 94.4 & & \\
\hline
\end{tabular}

Note. $n=2285$; BMI: body mass index; \% FB: body fat percentage; WC: waist circumference. ${ }^{*} p$ value. A Chi-square test $(\chi 2)$ was used to evaluate the degree of difference of the anthropometric data, anemia, and the academic areas of the university students. $p$ represents the probability that academic areas are differentiated with anthropometric data and anemia. ${ }^{* *}$ Statistical significance. 
TABLE 5: Analysis of the association between sociodemographic characteristics and overweight/obesity in university students.

\begin{tabular}{|c|c|c|c|c|c|c|}
\hline \multirow[t]{2}{*}{ Variable } & \multicolumn{2}{|c|}{$\begin{array}{l}\text { With overweight/ } \\
\text { obesity }\end{array}$} & \multicolumn{2}{|c|}{ No overweight/obesity } & \multirow[t]{2}{*}{$\chi^{2}$} & \multirow[t]{2}{*}{$p^{*}$} \\
\hline & $n$ & $\%$ & $n$ & $\%$ & & \\
\hline \multicolumn{7}{|l|}{ Age (years) } \\
\hline$<18$ & 97 & 13.2 & 266 & 17.2 & 13.972 & $0.003^{* *}$ \\
\hline $18-22$ & 467 & 63.4 & 997 & 64.4 & & \\
\hline $23-27$ & 126 & 17.1 & 225 & 14.5 & & \\
\hline$>27$ & 47 & 6.4 & 60 & 3.9 & & \\
\hline \multicolumn{7}{|l|}{ Sex } \\
\hline Women & 416 & 56.4 & 896 & 57.9 & 0.421 & 0.516 \\
\hline Men & 321 & 43.6 & 652 & 42.1 & & \\
\hline \multicolumn{7}{|l|}{ Marital status } \\
\hline Single & 720 & 97.7 & 1529 & 98.8 & 3.750 & 0.053 \\
\hline Married & 17 & 2.3 & 19 & 1.2 & & \\
\hline \multicolumn{7}{|l|}{ Region of origin } \\
\hline Coast & 361 & 49.0 & 725 & 46.8 & 1.017 & 0.797 \\
\hline Sierra & 212 & 28.8 & 458 & 29.6 & & \\
\hline Jungle & 110 & 14.9 & 248 & 16.0 & & \\
\hline Foreign & 54 & 7.3 & 117 & 7.6 & & \\
\hline \multicolumn{7}{|l|}{ Academic area } \\
\hline Humanities & 112 & 15.2 & 269 & 17.4 & 9.045 & $0.029^{* *}$ \\
\hline Business & 123 & 16.7 & 236 & 15.2 & & \\
\hline Health & 262 & 35.5 & 618 & 39.9 & & \\
\hline Engineering & 240 & 32.6 & 425 & 27.5 & & \\
\hline \multicolumn{7}{|l|}{$\% \mathrm{BF}$} \\
\hline Low & 0 & 0.0 & 12 & 0.8 & 659.734 & $<0.001^{* *}$ \\
\hline Normal & 88 & 11.9 & 938 & 60.6 & & \\
\hline High & 340 & 46.1 & 505 & 32.6 & & \\
\hline Very high & 309 & 41.9 & 93 & 6.0 & & \\
\hline \multicolumn{7}{|l|}{$\mathrm{WC}$} \\
\hline Normal & 318 & 43.1 & 1473 & 95.2 & 815.066 & $<0.001^{* *}$ \\
\hline High & 283 & 38.4 & 74 & 4.8 & & \\
\hline Very high & 136 & 18.5 & 1 & 0.1 & & \\
\hline
\end{tabular}

Note. $n=2285 ; \%$ FB: body fat percentage; WC: waist circumference. ${ }^{*} p$ value. A Chi-square test $(\chi 2)$ was used to evaluate the sociodemographic, academic, and anthropometric data of the university students. $p$ represents the probability that the mentioned data are associated with overweight/obesity. ${ }^{* *}$ statistical significance.

TABLE 6: Binary logistic regression analysis of factors associated with overweight/obesity in university students.

\begin{tabular}{|c|c|c|c|c|c|}
\hline Variable & $\mathrm{B}$ & SE & Wald & $p$ & $\mathrm{OR}_{\mathrm{B}}$ \\
\hline Age (years) $(0=<27 ; 1=\geq 27)$ & 0.73 & 0.28 & 6.70 & 0.01 & 2.07 \\
\hline $\operatorname{Sex}(0=$ woman, $1=\operatorname{man})$ & 0.98 & 0.14 & 46.78 & 0.00 & 2.68 \\
\hline Academic area $(0=$ other, $1=$ engineering $)$ & 0.33 & 0.13 & 6.10 & 0.01 & 1.39 \\
\hline Excess body fat $(0=$ no, $1=$ yes $)$ & 2.10 & 0.15 & 207.08 & 0.00 & 8.17 \\
\hline Raised WC $(0=$ no, $1=$ yes $)$ & 3.57 & 0.18 & 402.56 & 0.00 & 35.51 \\
\hline Constant & -3.61 & 0.17 & 470.83 & 0.00 & 0.03 \\
\hline
\end{tabular}

Note. $n=2285$; B: Beta coefficient, SE: standard error, $p$ : probability, $\mathrm{OR}_{\mathrm{B}}$ : Multivariate Odds Ratio.

contributing factor in the classification of BMI in young students [26-28]. These findings were consistent with national estimates, considering the same age group for the overweight category [29, 30]. Possible justifications include the fact that university students generally have unhealthy eating habits and inadequate nutrient intake [31]. Moreover, women may have a higher concentration of leptin, an appetite regulating hormone $[32,33]$. Furthermore, the prevalence was found to be similar among humanities, business, health sciences, and engineering students.
Likewise, in a study that examined a convenience sample of 175 health sciences students from Lima, it was found that $28.7 \%$ were overweight and $6.3 \%$ were obese [34].

The $\% \mathrm{BF}$, compared with the BMI, is the best indicator for classifying overweight and obesity $[35,36]$. In this study, the highest proportion of high and very high body fat percentage was observed in men compared to women, and these differences were significant. This finding is consistent with similar studies in which it has been observed that the majority of women students were healthy, while men 
obtained higher scores in overweight and obesity than women [37]. The possible reason for the lower \% FB rate among women students could be due to their desire to be slimmer due to concerns about body image during adolescence [38], a factor that could motivate going to the gym and doing aerobic exercises to reduce weight and maintaining a specific body image, while men identify with muscle development and tend to increase food intake [39]. In addition, this could be due, at least partially, to the fact that a greater proportion of men had a higher BMI; in fact, the results of the current study showed that having excess body fat significantly predicts being overweight/obese. Body fat percentage is possibly one of the most accurate measures of obesity [40]. Available data suggest that the prevalence of obese and overweight men is much higher than that of women in some regions [41], which represents a greater risk of morbidity, considering that men accumulate more visceral fat, which is highly related to a greater cardiovascular risk. In contrast, women accumulate more subcutaneous fat before menopause, which represents a protective factor against obesity and metabolic syndrome [42].

In this study, it was observed that the proportion of women students who presented a high and very high WC level was higher compared to men, and these differences are significant $(p<0.001)$. This result is supported by findings observed in other studies, in which WC was significantly higher in women $[43,44]$. However, these results are not consistent with the findings reported in a similar study [45]. WC is a better marker of abdominal fat and is an independent risk factor for cardiovascular disease [46]. When measured through imaging methods, it is directly associated with increased intraperitoneal fat [47]. WC is also considered a predictor of visceral adiposity and hypertension in young people [48]. Also, elevated waist circumference is an indicator of abdominal obesity and is the most common expression of insulin resistance and it has been identified as a powerful etiopathogenic factor for the development of type 2 diabetes mellitus and atherogenesis [49]. In the current study, having a high waist circumference is a predictor of overweight/obesity. However, an increase in WC is not necessarily associated with an increase in BMI and can be abnormal even when the BMI is within the normal range [50]. This would explain the fact that the women in our study had a lower prevalence of overweight and obesity according to BMI. Other studies suggest that the pattern of body fat distribution predicts metabolic diseases, regardless of the degree of overweight or obesity determined by BMI [51]. Our findings support the use of WC in screening as a valuable marker in identifying the risk of metabolic diseases in both men and women college students even when the BMI is normal.

Another important result to highlight in this study is that general obesity and high and very high waist circumference were very frequent among humanities, business, and engineering students. Students who were from the academic area of engineering were more likely to be overweight/obesity. These results could be due to inappropriate lifestyles, including unhealthy eating behaviors and sedentary behaviors. In fact, students enrolled in non-health-related colleges such as human nutrition, medicine, nursing, pharmacy, and others are expected to be less attentive to their eating habits [52]. In addition, the level of knowledge of these students on topics related to healthy eating and disease prevention is expected to be lower compared to health sciences students, which clearly can negatively impact their physical health [53]. Therefore, it is necessary to introduce healthy lifestyle interventions, particularly nutrition education programs, and physical activity, to improve the body weight status of university students, precisely those who are not enrolled in the faculties of health sciences.

On the other hand, in this study it was observed that the prevalence of anemia was lower among men and women. The prevalence of anemia is similar to that reported by Quispe et al. [54] in a study carried out on young people from Lima. Moreover, although the proportion of women with anemia was higher, similar results are reported in other studies [55, 56]; these results are generally explained simply by the loss of iron during menstruation. Women in this study have reached menarche. In the late teens, men quickly regain adequate iron stores, while women remain vulnerable to anemia as a result of menstrual blood loss. Therefore, they may remain anemic or become more anemic due to increased micronutrient requirements from menstruation, as well as from pregnancy and lactation [57]. However, it should be mentioned that there are factors not evaluated in this study that could explain the differences in the proportions of women university students with anemia compared to men; these factors could be ferritin, dietary factors, and higher testosterone in men [58].

4.1. Strengths and Limitations. The strengths of our study include a large sample size. In addition, the evaluators of the anthropometric and biochemical indicators were professional nutritionists, nurses, and specialized medical technologists. However, there are certain limitations that must be considered. For example, it did not take into account possible factors associated with the study variables such as dietary intake and physical exercise, so it is recommended to include them in future research to have more knowledge about the behavior of these variables. In addition, it is a nonprobabilistic sample made up of volunteer university students; therefore, the results of the study cannot be generalized, so it is recommended that future studies consider the calculation of the sample size as a test power established a priori and a method of random sample selection that allows having quantities of samples similar by groups.

\section{Conclusions}

It was evidenced that the proportion of men who were overweight/obesity was slightly higher compared to women. In addition, there is a higher proportion of students with high and very high levels of body fat in males. However, there was a higher percentage of women who presented high and very high WC levels compared to men. On the other hand, the studied population presented a low prevalence of 
anemia. Several factors associated with overweight/obesity were identified. In educational settings, particularly in universities, healthy lifestyles should be promoted, including healthy dietary practices, physical activity, and healthy behaviors in general to reduce the prevalence of overweight and obesity. Also, university teachers must actively participate in this process, because, as influencers and agents of change, they can significantly influence the lifestyles and health of students.

\section{Data Availability}

The datasets used and analyzed during the present study are available from the corresponding author on reasonable request.

\section{Conflicts of Interest}

The authors declare that they have no conflicts of interest.

\section{Authors' Contributions}

R. B. Q. Castañeda and J. Turpo-Chaparro designed the study, participated in data collection, and wrote the first draft of the manuscript. J. H. Torres, J. Saintila, and P. G. R. Mamani participated in the design of the study, analyzed and interpreted the data, and assisted in the drafting and final writing of the manuscript. All authors read and approved the final manuscript, agree with the manuscript and declare that the content has not been published in another journal.

\section{References}

[1] G. Sogari, C. Velez-Argumedo, M. I. Gómez, and C. Mora, "College students and eating habits: a study using an ecological model for healthy behavior," Nutrients, vol. 10, no. 12, 2018.

[2] Y. Chen, X. Liu, N. Yan et al., "Higher academic stress was associated with increased risk of overweight and obesity among college students in China," International Journal of Environmental Research and Public Health, vol. 17, no. 15, pp. 1-12, 2020.

[3] I. NS. Cerca, del 70\% de adultos peruanos padecen de obesidad y sobrepesoLima, Perú, 2019, https://web.ins.gob.pe/es/prensa.

[4] X. Ji, H. Zhao, M. Wang, Y. Li, C. Zhang, and X. Wang, "Study of correlations between metabolic risk factors, PWV and hypertension in college students," Clinical and Experimental Hypertension, vol. 42, no. 4, pp. 376-380, 2020.

[5] A. Garcia-Hermoso, A. Tordecilla-Sanders, J. E. CorreaBautista, M. D. Peterson, M. Izquierdo, and D. PrietoBenavides, "Handgrip strength attenuates the adverse effects of overweight on cardiometabolic risk factors among collegiate students but not in individuals with higher fat levels," Scientific Reports, vol. 9, no. 1, pp. 1-8, 2019.

[6] R. Puhl and K. D. Brownell, "Bias, discrimination, and obesity," Obesity Research, vol. 9, no. 12, pp. 788-805, 2001.

[7] H. A. Mohd Abd Majid, S. K. Ahmad Sharoni, J. Annuar, S. N. Syed Yasin, and R. Raju, "Carbohydrates intake preference among university students towards balanced intake practice," Food Research, vol. 4, no. 5, pp. 1469-1479, 2020.

[8] J. Saintila, T. E. Lozano, Y. E. Calizaya-Milla, M. White, and S. Huancahuire-Vega, "Nutritional knowledge, anthropometric profile, total cholesterol, and motivations among Peruvian vegetarians and non-vegetarians," Nutrición Clínica y Dietética Hospitalaria, vol. 41, no. 1, pp. 91-98, 2021.

[9] S. Díaz, F. González, and K. Arrieta, "Physical activity levels associated with sociodemographic, anthropometric and behavioral factors in university students of Cartagena (Colombia)," Salud Uninorte, vol. 30, no. 3, pp. 405-417, 2014.

[10] E. Núñez-Robles, C. Huapaya-Pizarro, R. Torres-Lao, S. Esquivel-León, V. Suarez-Moreno, and M. Yasuda-Espinoza, "Prevalence of cardiovascular and metabolic risk factors in school students, university students, and women from community-based organizations in the districts of Lima, Callao, La Libertad and Arequipa, Peru 2011," Revista Peruana de Medicina Experimental y Salud Pública, vol. 31, no. 4, pp. 652-659, 2014.

[11] D. Warrell, T. Cox, and J. Firth, Oxford Textbook of Medicine, Oxford University Press, Oxford, UK, 6 edition, 2018.

[12] WHO, The Global Prevalence of Anaemia in 2011, WHO, Geneva, Switzerland, 2015, https://www.who.int/nutrition/ publications/micronutrients/global_prevalence_anaemia_ 2011/en/.

[13] INEI, Gobierno del Perú. Encuesta Demográfica y de Salud Familiar-ENDES 2015Lima, Perú, 2015, https://www.inei.gob. pe/media/MenuRecursivo/publicaciones_digitales/Est/ Lib1356/.

[14] M. C. Nelson, M. Story, N. I. Larson, D. Neumark-Sztainer, and L. A. Lytle, "Emerging adulthood and college-aged youth: an overlooked age for weight-related behavior change," Obesity, vol. 16, no. 10, pp. 2205-2211, 2008.

[15] S. Riveros-Chavez, M. Apolaya-Segura, S. Riveros-Chavez, and M. Apolaya-Segura, "Características clínicas y epidemiológicas del estado nutricional en ingresantes a la facultad de medicina humana de una universidad privada," Acta Médica Peruana, vol. 37, no. 1, pp. 27-33, 2020.

[16] J. Rabanales-Sotos, M. Evangelina Villanueva-Benites, J. Jacinto-Magallanes-Castilla, Z. E. Leitón-Espinoza, Á. López-González, and J. López-Torres-Hidalgo, "Prevalence of overweight and obesity among health sciences students in the amazonia region of Peru," Healthcare, vol. 8, p. 538, 2020.

[17] R. M. P. Iparraguirre, M. M. Porras, A. H. De La Cruz, and M. L. Días Bonilla, "Prevalence of overweight and obesity in young Peruvian students at national university of center of Peru-region junin-huancayo," Obesity Medicine, vol. 19, Article ID 100242, 2020.

[18] Ministerio de salud (MINSA), Guía técnica para la valoración nutricional antropométrica de la persona adulta, https:// repositorio.ins.gob.pe/xmlui/bitstream/handle/INS/225/ CENAN-0067.pdf? sequence $=1$ \&isAllowed $=y, 2012$.

[19] J. R. A. Cruz, M. D. C. Armesilla, and Á. Herrero de Lucas, "Protocolo de valoración de la composición corporal para el reconocimiento médico-deportivo. Documento de Consenso del Grupo Español de Cineantropometría de la Federación Española de Medicina del Deporte," Arch Med Deport, vol. xxvi, no. 131, pp. 166-179, 2009.

[20] D. Gallagher, S. B. Heymsfield, M. Heo, S. A. Jebb, P. R. Murgatroyd, and Y. Sakamoto, "Healthy percentage body fat ranges: an approach for developing guidelines based on body mass index," American Journal of Clinical Nutrition, vol. 72, no. 3, pp. 694-701, 2000.

[21] M. I. N. S. A. Gobierno del Perú, Norma técnica de salud para el manejo terapéutico y preventivo de la anemia en niños, adolescentes, mujeres gestantes y puérperas, http://ftp://ftp2. minsa.gob.pe/normaslegales/2017/RM_250-2017-MINSA. PDF, 2017. 
[22] L. Di Milia, C. Vandelanotte, and M. J. Duncan, "The association between short sleep and obesity after controlling for demographic, lifestyle, work and health related factors," Sleep Medicine, vol. 14, no. 4, pp. 319-323, 2013.

[23] H. Al-Kilani, M. Waly, and R. Yousef, "Trends of obesity and overweight among college students in Oman: a cross sectional study," Sultan Qaboos University Medical Journal, vol. 12, no. 1, pp. 69-76, 2012.

[24] D. E. Lopez-Lopez, I. K. Saavedra-Roman, Y. E. CalizayaMilla, and J. Saintila, "Food addiction, saturated fat intake, and body mass index in Peruvian adults: a cross-sectional survey," Journal of Nutrition and Metabolism, vol. 2021, Article ID 9964143, 7 pages, 2021.

[25] D. A. Soares and S. M. Barreto, "Sobrepeso e obesidade abdominal em adultos quilombolas, Bahia, Brasil," Cadernos de Saúde Pública, vol. 30, no. 2, pp. 341-354, 2014.

[26] J. Wang, Y. Chen, Y. Jin, L. Zhu, and Y. Yao, "Sleep quality is inversely related to body mass index among university students," Revista da Associação Médica Brasileira, vol. 65, no. 6, pp. 845-850, 2019.

[27] I. Wronka, E. Suliga, and R. Pawlińska-Chmara, "Socioeconomic determinants of underweight and overweight in female Polish students in 2009," Anthropologischer Anzeiger, vol. 69, no. 1, pp. 85-96, 2012.

[28] A. Długosz, E. Niedźwiedzka, T. Długosz, and L. Wądołowska, "Socio-economic status as an environmental factor-incidence of underweight, overweight and obesity in adolescents from less-urbanized regions of Poland," Annals of Agricultural and Environmental Medicine, vol. 22, no. 3, pp. 518-523, 2015.

[29] J. E. Villena, "Prevalencia de sobrepeso y obesidad en el Perú," Rev Peru Ginecol Obs, vol. 63, no. 4, p. 593, 2017.

[30] Instituto Nacional de Estadística e Informática (INEI), Gobierno del Perú. Nota de Prensa, INEI, Lima, Perú, 2016.

[31] J. Choi, "Impact of stress levels on eating behaviors among college students," Nutrients, vol. 12, no. 5, 2020.

[32] A. Falorni, V. Bini, D. Molinari et al., "Leptin serum levels in normal weight and obese children and adolescents: relationship with age, sex, pubertal development, body mass index and insulin," International Journal of Obesity, vol. 21, no. 10, pp. 881-890, 1997.

[33] R. N. Al-Harithy, "Relationship of leptin concentration to gender, body mass index and age in Saudi adults," Saudi Medical Journal, vol. 25, no. 8, pp. 1086-1090, 2004.

[34] L. Acuña-Medina, Y. Arias-Quispe, D. Chipana-Collahua, L. Sifuentes-Gómez, and P. Quispe-Rosales, "Exceso de peso y actividad física en estudiantes de enfermería de una universidad del norte de Lima," Rev Peru salud pública $y$ comunitaria, vol. 1, no. 1, pp. 26-35, 2018.

[35] H. Kilani and A. Abu-Eisheh, "Optimum anthropometric criteria for ideal body composition related fitness," Sultan Qaboos University Medical Journal, vol. 10, no. 1, pp. 74-79, 2010.

[36] Y. F. Osman, S. K. Muscati, S. S. Ganguly, M. Khan, and B. AlSharji, "Progression of obesity among Seeb school children in Oman. A preliminary study," Saudi Medical Journal, vol. 25, no. 12, pp. 2038-2040, 2004.

[37] H. Al-Kilani, M. Waly, and R. Yousef, "Trends of obesity and overweight among college students in Oman a cross sectional study," Sultan Qaboos University Medical Journal, vol. 12, no. 1, pp. 620-627, 2012.

[38] A. E. Field, L. Cheung, A. M. Wolf, D. B. Herzog, S. L. Gortmaker, and G. A. Colditz, "Exposure to the mass media and weight concerns among girls," Pediatrics, vol. 103, no. 3, p. e36, 1999.

[39] C. Tarqui-Mamani, D. Alvarez-Dongo, P. L. EspinozaOriundo, and J. R. Sanchez-Abanto, "Análisis de la tendencia del sobrepeso y obesidad en la población peruana," Revista Española de Nutrición Humana y Dietética, vol. 21, no. 2, pp. 137-147, 2017.

[40] T. C. Mills, "Predicting body fat using data on the BMI," Journal of Statistics Education, vol. 13, no. 2, 2017 Jan.

[41] K.-B. Kim and Y.-A. Shin, "Males with obesity and overweight," Journal of Obesity \& Metabolic Syndrome, vol. 29, no. 1, pp. 18-25, 2020.

[42] B. F. Palmer and D. J. Clegg, "The sexual dimorphism of obesity," Molecular and Cellular Endocrinology, vol. 402, pp. 113-119, 2015.

[43] N. Ahmad, S. I. M. Adam, A. M. Nawi, M. R. Hassan, and H. F. Ghazi, "Abdominal obesity indicators: waist circumference or waist-to-hip ratio in Malaysian adults population," International Journal of Preventive Medicine, vol. 7, no. 8, 2016.

[44] B. K. Jacobsen and N. A. Aars, "Changes in waist circumference and the prevalence of abdominal obesity during 19942008-cross-sectional and longitudinal results from two surveys: the Tromsø Study,” BMC Obesity, vol. 3, no. 1, 2016.

[45] N. T. T. Tran, C. L. Blizzard, K. N. Luong et al., "The importance of waist circumference and body mass index in cross-sectional relationships with risk of cardiovascular disease in Vietnam," PLoS One, vol. 13, no. 5, Article ID e0198202, 2018.

[46] D. R. Weber, L. E. Levitt Katz, B. S. Zemel et al., "Anthropometric measures of abdominal adiposity for the identification of cardiometabolic risk factors in adolescents," Diabetes Research and Clinical Practice, vol. 103, no. 3, pp. e14-e17, 2014.

[47] S. M. Grundy, I. J. Neeland, A. T. Turer, and G. L. Vega, "Waist circumference as measure of abdominal fat compartments," Journal of Obesity, vol. 2013, Article ID 454285, 12 pages, 2013.

[48] W. L. Cheah, C. T. Chang, H. Hazmi, and G. W. F. Kho, "Using anthropometric indicator to identify hypertension in adolescents: a study in sarawak, Malaysia," International Journal of Hypertension, vol. 2018, Article ID 6736251, 13 pages, 2018

[49] J. P. Després, I. Lemieux, J. Bergeron, P. Pibarot, P. Mathieu, and E. Larose, "Abdominal Obesity and the Metabolic Syndrome: Contribution to global cardiometabolic risk," Arteriosclerosis, Thrombosis, and Vascular Biology, vol. 28, pp. 1039-1049, 2008.

[50] D. C. Pazin, C. F. Rosaneli, M. Olandoski et al., "Waist circumference is associated with blood pressure in children with normal body mass index: a cross-sectional analysis of 3,417 school children," Arquivos Brasileiros de Cardiologia, vol. 109, no. 6, pp. 509-515, 2017.

[51] M. N. Iampolsky, F. I. S. d. Souza, and R. O. S. Sarni, "Influência do índice de massa corporal e da circunferência abdominal na pressão arterial sistêmica de crianças," Revista Paulista de Pediatria, vol. 28, no. 2, pp. 181-187, 2010.

[52] S. AlJohani, M. Salam, A. BaniMustafa, A. R. Z. Zaidi, A. A. Aljohani, and A. Almutairi, "Dietary habits of students enrolled in faculties of health sciences: a cross-sectional study," Cureus, vol. 11, no. 10, 2019, http://pmc/articles/ PMC6881085/.

[53] A. Montero, N. Ubeda, and A. Gonzales, "Evaluación de los hábitos alimentarios de una población de estudiantes 
universitarios en relación con sus conocimientos nutricionales," Nutricion Hospitalaria, vol. 21, no. 4, pp. 466-473, 2015.

[54] C. Quispe and E. Gutierrez, "Consumo de alimentos y anemia en adolescentes mujeres de un colegio nacional de Lima," Revista Cubana de Hematología e Inmunología y Hemoterapia, vol. 34, no. 1, pp. 58-67, 2018.

[55] H. A. Hamali, A. A. Mobarki, M. Saboor et al., "Prevalence of anemia among Jazan university students," International Journal of General Medicine, vol. 13, pp. 765-770, 2020.

[56] L. Shaban, A. Al-Taiar, A. Rahman, R. Al-Sabah, and O. Mojiminiyi, "Anemia and its associated factors among Adolescents in Kuwait," Scientific Reports, vol. 10, no. 1, p. $5857,2020$.

[57] A. M. Prentice, "Nutrition challenges and issues of relevance to adolescents in low- and middle-income countries," Health and Nutrition in Adolescents and Young Women: Preparing for the Next Generation, vol. 80, pp. 49-59, 2014.

[58] E. Bachman, T. G. Travison, S. Basaria et al., "Testosterone induces erythrocytosis via increased erythropoietin and suppressed hepcidin: evidence for a new erythropoietin/hemoglobin set point," The Journals of Gerontology Series A: Biological Sciences and Medical Sciences, vol. 69, no. 6, pp. 725-735, 2014. 